\title{
Antimicrobial use in hospitalized patients with renal dysfunction: A multiprofessional approach
}

\author{
O uso de antimicrobianos em pacientes com disfunção renal hospitalizados: Uma abordagem \\ multiprofissional
}

El uso de antimicrobianos en pacientes hospitalizados con disfunción renal: Un enfoque multiprofesional

\begin{abstract}
Introduction: The monitoring of nephrotoxic antimicrobial use and the identification of probable problems related to their use in patients with renal risk factors is of the utmost importance, mainly regarding the safety and protection of patients' health. The present study aimed to analyze the use of restricted-use antimicrobials in hospitalized patients with renal dysfunction. Methods: This is a cross-sectional retrospective study carried out from January to March 2015, which included the following variables: age, gender, comorbidities, type of kidney disease, hospitalization unit, and antimicrobial sused, classified according to the ATC (Anatomical Therapeutic Chemical) methodology. Results and Discussion: records of renal dysfunction were found in 113 monitored patients, most of which were males, with CKD, and aged between 60 and 89 years. The most commonly prescribed restricted-use antimicrobials were from the broadspectrum penicillin group. Conclusions: Safety in pharmacotherapy may be decisive in the clinical outcome of renal patients, so the multiprofessional contribution plays an important role in maintaining a favorable clinical condition.
\end{abstract}

Keywords: Antimicrobial; Kidney diseases; Nephrotoxicity; Patient care team.

\section{Resumo}

Introdução: o acompanhamento da utilização de antimicrobianos nefrotóxicos e a identificação dos prováveis problemas relacionados ao uso, em pacientes com risco renal, denota sua real importância principalmente para a segurança e proteção da saúde dos pacientes. Objetivo: analisar a utilização de antimicrobianos de uso restrito, em pacientes portadores de disfunção renal hospitalizados. Métodos: trata-se de um estudo retrospectivo de corte transversal realizado no período de janeiro a março de 2015, no qual foram coletadas as seguintes variáveis: idade, gênero, comorbidades, tipo de doença renal, unidade de internação, antimicrobianos utilizados, classificados de acordo com a metodologia ATC. Resultados e Discussões: foram encontrados registros de disfunção renal em 113 pacientes acompanhados, maioria do sexo masculino, com DRC e com idade entre 60 e 89 anos. Os antimicrobianos de uso restrito mais prescritos foram do grupo das penicilinas de amplo espectro. Conclusões: a segurança na farmacoterapia pode ser decisiva no desfecho clínico de pacientes renais, assim a contribuição multiprofissional desenvolve um papel importante na manutenção de uma condição clínica favorável.

Palavras-chave: Antimicrobiano; Doenças renais; Nefrotoxicidade; Equipe multiprofissional. 


\begin{abstract}
Resumen
Introducción: el seguimiento del uso de antimicrobianos nefrotóxicos y la identificación de probables problemas relacionados con su uso, en pacientes con riesgo renal, muestra su importancia real, principalmente para la seguridad y protección de la salud de los pacientes. Objetivo: analizar el uso de antimicrobianos de uso restringido en pacientes hospitalizados con disfunción renal. Métodos: se trata de un estudio transversal retrospectivo realizado de enero a marzo de 2015, en el que se recogieron las siguientes variables: edad, sexo, comorbilidades, tipo de enfermedad renal, unidad de hospitalización, antimicrobianos utilizados, clasificados según la metodología ATC . Resultados y Discusiones: se encontraron registros de disfunción renal en 113 pacientes seguidos, en su mayoría varones, con ERC y con edades comprendidas entre 60 y 89 años. Los antimicrobianos de uso restringido más recetados fueron del grupo de penicilina de amplio espectro. Conclusiones: la seguridad en la farmacoterapia puede ser determinante en la evolución clínica del paciente renal, por lo que el aporte multiprofesional juega un papel importante en el mantenimiento de una condición clínica favorable.
\end{abstract}

Palabras clave: Antimicrobiano; Enfermedades renales; Nefrotoxicidad; Equipo multiprofesional.

\title{
1. Introduction
}

According to the Ministry of Health, Chronic Kidney Disease (CKD) has been considered a public health problem. Analysis of the National Health and Nutrition Examination Survey (NHANES) has shown that approximately 13\% of the US adult population has some degree of renal function loss (Brasil, 2014). In a prospective multicenter study - Longitudinal Study of Adult Health (Estudo Longitudinal de Saúde do Adulto- ELSA-Brazil) -carried out in the main Brazilian capitals, it was demonstrated that almost 9\% of the participants had CKD, that is, they had a decrease in GFR (Glomerular Filtration Rate), with the overall prevalence of CKD being higher in men (10.1\%) than in women (7.9\%) (Barreto et al., 2015).

Another important study carried out in 2003 in the city of Bambuí, state of Minas Gerais, Brazil, in which more than 2,000 individuals were evaluated, showed a change in serum creatinine, a marker of renal dysfunction, which was more frequent in elderly individuals (Passos, Barreto \& Lima-Costa, 2003). Another study carried out in 2004 on hypercreatinemia in a population of 1,439 adults in the city of Salvador (Bahia) found a prevalence of elevated serum creatinine of 3.1\%, being $5.2 \%$ in men and $1.6 \%$ in women (Lessa, 2004).

Regarding Acute Kidney Injury (AKI), the literature shows data that are a matter of concern, confirming this condition is a frequent and severe complication during hospitalization. AKI shows a high prevalence in hospital admissions, with rates of up to $15 \%$, as well as in Intensive Care Units (ICU), of about $40 \%$. It also has a high mortality rate, affecting $80 \%$ of the patients admitted to the ICU, and 13\% of the survivors will require dialysis (Peres, Wandeur \& Matsuo, 2015; Iavechia et al., 2015).

In addition to these indicators, the Brazilian Chronic Dialysis Survey carried out by the Brazilian Nephrology Society (SBN) in 2014, highlighted that the estimated total number of dialysis patients in the country that year was 112,004, which represents an increase of 20,000 patients in the last 4 years starting RRT (Renal Replacement Therapy), that is, an average annual increase of 5\% (Sesso, Lopes, Thomié, Lugon \& Santos, 2014).

Despite this considerable increase, the prevalence of patients under going RRT in Brazil is below those of countries with a similar profile, indicating the need for adequate identification and treatment of patients with risk factors for Kidney Disease(KD), as well as their early diagnosis, aiming at the integral care of these patients, having as main objectives the reduction of unfavorable outcomes, such as cardiovascular mortality and progression to end-stage chronic kidney disease(ESCKD). Among the risk factors involved in the disease progression, it is important to mention the use of nephrotoxic agents, as well as medications that require adjustment in patients with renal alterations (Brasil, 2014).

From this perspective, monitoring the use of nephrotoxic antimicrobials and the identification of the probable problems related to their use in patients with renal risk factors is of the utmost importance, mainly for the safety and protection of patients' health. 
The present study aimed to analyze the use of restricted-use antimicrobials in hospitalized patients with renal dysfunction.

\section{Methodology}

This is an observational, retrospective cross-sectional study, as described by Koche (2011), carried out from January to March 2015. The population comprised patients with electronic records of renal dysfunction who received restricted-use antimicrobials. Patients included in this study were adults of both genders, treated by a multidisciplinary team, with a record of renal dysfunction and who received restricted-use antimicrobials (ATM). Patients who were not monitored and who did not have kidney injury while using ATM were not included in the study.

The study was carried out in a philanthropic hospital located in the city of Salvador, state of Bahia, Brazil, characterized by its large size, with more than 400 beds divided in to the following units: Inpatient units, Maternity, Surgical Center and Closed Units, in addition of being a reference in intensive treatment in several specialties.

The hospital has a computerized system used for the management of supplies and electronic medical records and, therefore, an environment that is favorable for multiprofessional care assessment.

The data were collected from the information gathered during the follow-up of hospitalized patients, considering the following variables: age, gender, comorbidities, type of kidney injury, hospitalization unit and ATM used, which were classified according to the ATC (Anatomical Therapeutic Chemical) method, considering their indication for use. Subsequently, an analysis of the follow-up of patients receiving antimicrobials was performed together with the health team and distributed per hospitalization unit. The present study was approved by the Research Ethics Committee under Opinion n. 1.615. 965 .

\section{Results}

A total of 113 electronic medical records were found of patients with renal dysfunction who were being monitored, most of which were males (51\%), 52 of them predominantly with CKD (46\%) and 80 were aged 60 to 89 years (70.8\% \%). Table I shows the distribution of the age group by type of kidney injury. A total of 104 of them (92\%) had at least one comorbidity, most of them with systemic arterial hypertension (SAH), with a prevalence of $75 \%$. 
Table 1: Type of kidney injury according to age group. Sociodemographic characteristics of patients with renal dysfunction admitted to a Philanthropic Hospital in Salvador-BA, 2015.

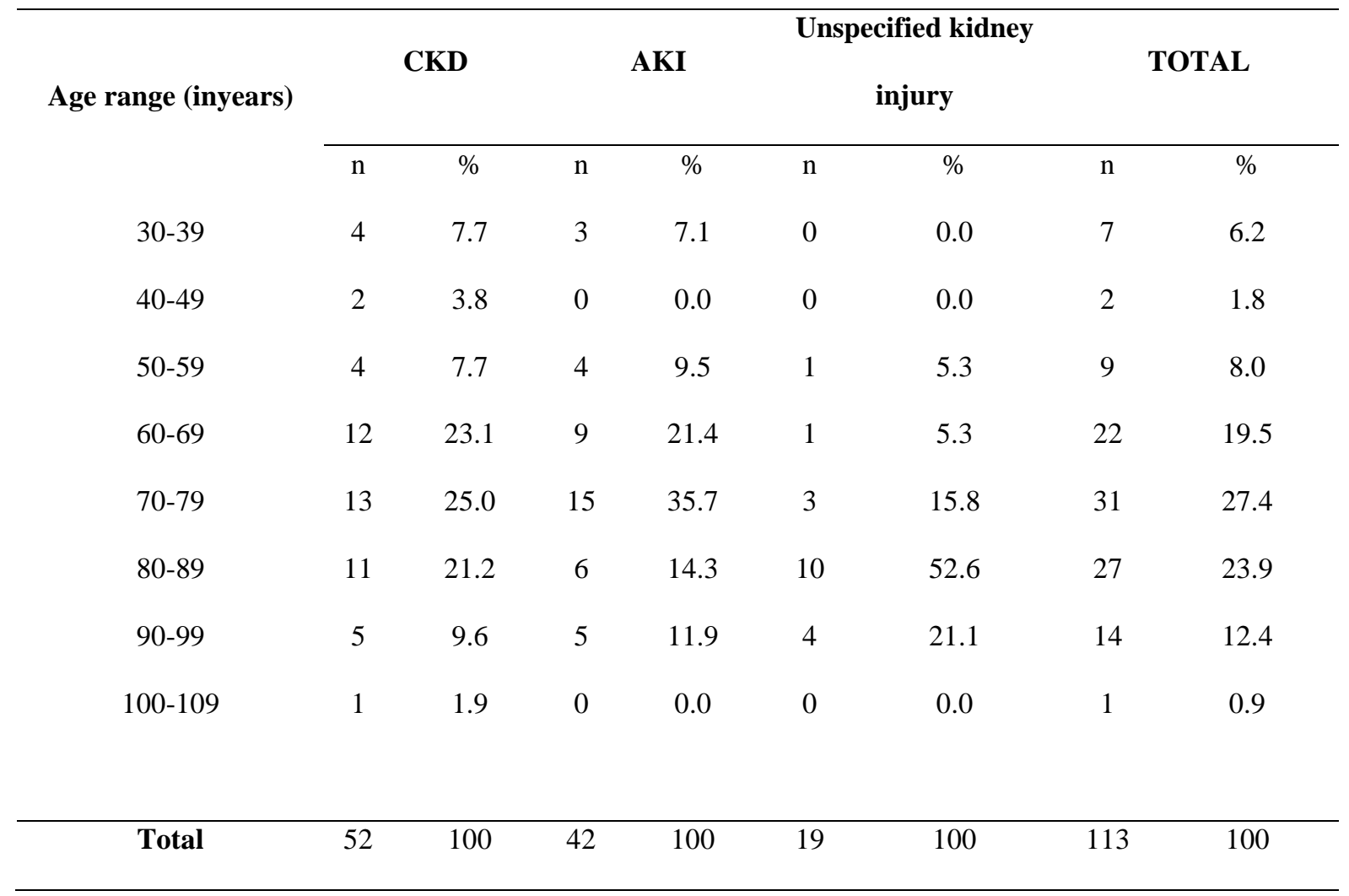

Source: Authors.

The most often prescribed restricted antimicrobials were the broad-spectrum penicillins (Piperacillin + Tazobactam), followed by Carbapenems (Meropenem and Ertapenem), as shown in Table II. The main causes associated with their use in patients with renal problems were:sepsis in 55 (48.7\%); Respiratory Tract Infections in $25(22.1 \%)$ and Urinary Tract Infections in 18 of them (15.9\%). 
Table 2. Use of restricted antimicrobials, by ATC class, prescribed to patients with kidney dysfunction at a Philanthropic Hospital of Salvador-BA, 2015.

\begin{tabular}{|c|c|c|}
\hline Medications & $\mathbf{n}$ & $\%$ \\
\hline \multicolumn{3}{|l|}{ J- Anti-infective drugs for systemic use } \\
\hline \multicolumn{3}{|l|}{ J01AA- Tetracyclines } \\
\hline J01AA12- Tigecycline & 8 & 3 \\
\hline \multicolumn{3}{|l|}{ J01C- Penicillins } \\
\hline J01CR50- Piperacillin + Tazobactam & 86 & 30 \\
\hline \multicolumn{3}{|l|}{ J01D- Otherantibacterial beta-lactams } \\
\hline \multicolumn{3}{|l|}{ J01DH- Carbapenems } \\
\hline J01DH02- Meropenem & 62 & 22 \\
\hline J01DH03- Ertapenem & 15 & 5 \\
\hline \multicolumn{3}{|l|}{ J01X- OtherAntibacterial drugs } \\
\hline \multicolumn{3}{|l|}{ J01XA- Glycopeptides } \\
\hline J01XAD1- Vancomycin & 14 & 5 \\
\hline J01XAD2- Teicoplanin & 27 & 10 \\
\hline \multicolumn{3}{|l|}{ J01XB- Polymyxins } \\
\hline J01XB02- Polymyxin B & 16 & 6 \\
\hline \multicolumn{3}{|l|}{ J01XX- Other Antibacterial drugs } \\
\hline J01XX08- Linezolid & 10 & 4 \\
\hline J01XX09- Daptomycin & 17 & 6 \\
\hline \multicolumn{3}{|l|}{ J02A- Other Antimycotic drugs for Systemic Use } \\
\hline J02AX04- Caspofungin & 19 & 7 \\
\hline J02AX05- Micafungin & 8 & 3 \\
\hline
\end{tabular}

Regarding the follow-up and distribution of interventions related to the use of antimicrobials per hospitalization unit (Figure I), $11(11.8 \%)$ were performed in the open units and $82(88.2 \%)$ in the closed units, predominantly in the Adult ICU in40 cases (43\%), followed by the semi- intensive unit in 16 (17.2\%), Gastro-Hepatic Unit in 15 (16.1\%), Cardiac ICU in 6 $(6.5 \%)$ and Coronary Unit in 5 cases $(5.4 \%)$. 
Figure 1. Interventions aimed at monitoring the use of restricted antimicrobials for patients with renal impairment, per hospitalization unit. Salvador-BA, 2015.

\begin{tabular}{|c|c|c|c|}
\hline Gastro-hepatic Unit & & \multicolumn{2}{|l|}{$16,1 \%$} \\
\hline Cardiac ICU & $6,5 \%$ & \multirow{3}{*}{$17,2 \%$} & \\
\hline Semi-intensive unit & & & \multirow{4}{*}{$43 \%$} \\
\hline Coronary Unit & $5,4 \%$ & & \\
\hline Adult ICU & & & \\
\hline Open Unit & \multicolumn{2}{|c|}{$11,8 \%$} & \\
\hline
\end{tabular}

Source: Authors.

\section{Discussion}

The findings in the present study indicate a predominance of the elderly population, aged between 60 and 89 years, with a diagnosis of CKD and AKI. These data are similar to those found in the census carried out by the SBN, as well as data from other studies that established the epidemiological profile of patients with chronic kidney disease (Sesso et al, 2014; Sampaio, Coelho, Pinto \& Osteme, 2013; Cherchiglia et al, 2010). Regarding patients with AKI, there is an agreement with data from other studies, which found a higher AKI incidence in patients over 60 years of age (Peres, Wandeur \& Matsuo, 2015; Iavechia et al, 2015; Cruz et al, 2014).

These results should be discussed considering the epidemiological transition currently experienced in the country, demonstrated by the decrease in mortality due to infectious diseases and the increase of non-communicable chronic diseases (Oliveira \& Junior, 2016).Hence, the incidence of patients with KD in this age group occurs due to the progressive renal function loss, as a result of the anatomical and functional changes that occur in the kidneys as the population ages (Franco \& Fernandes, 2013).

Regarding gender, there is a predominance of renal dysfunction in the male population as shown in the present study, as well as in other studies (Iavechia et al, 2015; Sesso et al, 2014). This population is more exposed to risk factors, mainly family history of the disease, smoking, Cardiovascular Disease, SAH, and Diabetes Mellitus, among others (Passos, Barreto \& Lima-Costa, 2003; Lessa, 2004; Iavechia et al., 2015).

In this study, we identified the restricted-use antimicrobials most of ten prescribed to patients with renal dysfunction in the hospital setting. The use of the ATC classification allowed the identification of the most commonly prescribed ATM, which are penicillins, particularly Piperacillin + Tazobactam, followed by Carbapenems, especially Meropenem and Ertapenem, as well as glycopeptides (Vancomycin and Teicoplanin). However, other studies, which evaluated the prescription of antimicrobials, indicate cephalosporins as the most often prescribed ATM (Silva, 2012; Rodrigues \& Bertoldi, 2010; Dantas et al., 2015; Diefenthaeler, 2007).

In this case, it is important emphasize that the performed studies were not specific for renal patients; moreover, the use of restricted-use antimicrobials is associated to the hospital clinical specialties, the type of infection and the institution's ATM use policy (Diefenthaeler, 2007).

Treatment adequacy to the context of the CKD patient is also extremely important to avoid or minimize the nephrotoxic effects of certain substances, contributing to prevent or delay the progression of kidney disease. In the present 
study, the use of nephrotoxic antimicrobials was observed in a small number of cases, which shows the careful choice of antimicrobials according to renal function.The ATM that were prescribed to patients with renal dysfunction must have their dose adjusted, which is done by adjusting dosage according to the patient's glomerular filtration rate,considering its nephrotoxic characteristics (San-Martin \& Muner, 2013) The renal side effects are usually silent, especially in the initial phases and, therefore, clinical surveillance is required. It is also important to obtain a diagnosis of nephrotoxicity as soon as possible, aiming to adjust the dose or discontinue the medication, preventing kidney damage (Moreira, 2012).

This pharmacological class should only be used for therapeutic purposes when there is a clinical or microbiological suspicion of infection (Lerma et.al., 2010). The study showed that sepsis was the most frequent indication for prescribing restricted-use ATM to patients with renal dysfunction. From this perspective, an important study (Sampaio et al, 2013) carried out in an ICU of a tertiary hospital in the Northeast of Brazil emphasized that $46.15 \%$ of patients admitted to the institution had AKI secondary to sepsis. Among the several types of infections to which this subgroup of patients is susceptible, the most relevant are those related to vascular access (Leite \& Sousa, 2016), which reinforces the importance of creating institutional protocols recommending the antimicrobial agents, their doses and routes of administration that are more adequate for the treatment, aiming to guide the healthcare team's decision-making for the prevention and treatment of infections and associated causes.

Pharmacotherapeutic follow-up was mainly performed in closed intensive care units, which are intended for patients receiving specialized care and who, in many situations, are critically-ill patients with a longer hospitalization period and therefore requiring careful monitoring. Thus, the multiprofessional team must develop skills to take part in the entire process involving drug administration, aiming, among others, to contribute to patient care, to rationalize drug therapy with the objective of maximizing safety and therapeutic results (Pilau, Hegele \& Heineck, 2015).

In this study, most interventions were carried out mainly in the adult ICU, since patients in an intensive care unit are prone to infections and often require antimicrobial therapy. It is estimated that, during hospitalization, approximately $20 \%$ to $40 \%$ of patients receive antimicrobials for infection treatment and prevention (Marsilio, Silva \& Bueno, 2016). Similarly, a study showed that, in most cases, renal patients were treated in the intensive care unit (66.4\%), that is, a large proportion of hospitalized patients admitted to the ICU have renal dysfunction (Oliveira, Alves \& Bezerra, 2016).

Taking into account the complex follow-up of patients with $\mathrm{KD}$, it is important to consider some parameters, which include: laboratory tests, clinical history, and particularly, regarding the antimicrobial dose adjustment for renal function, it is important to take into consideration the risk / benefits, emphasizing the need for a broad clinical view by all the professionals involved in the care of these patients.

\section{Conclusion}

The study allowed the identification of the sociodemographic and clinical profiles of patients with kidney disease. Considering the abovementioned facts, it is important to know about these characteristics, aiming at providing adequate subsidies to help with the pharmacotherapeutic care, carefully assessing medications that may aggravate this condition. The results found regarding the infectious diagnosis more often related to the use of antimicrobials, reinforce the creation of institutional protocols, which contain different clinical situations, including some patients'special situations and recommendations on the antimicrobials, their doses and routes of administration that are the most adequate for the treatment, aiming to guide the decision-making by the health care team in the prevention and treatment of infections and associated causes.

Pharmacotherapy safety can be decisive in the clinical outcome of renal patients, so the multiprofessional contribution plays an important role in maintaining a favorable clinical condition. The contribution of the health team brings direct benefits 
to the hospital unit and, thus, problems related to drug administration can be minimized or eliminated. There are few national studies that demonstrate multidisciplinary action for patients with renal dysfunction, requiring a need for research in this area to serve as technical support, in addition to increasing the safety of drug therapy and the quality of care provided.

\section{References}

Barreto, S.M., Ladeira, R.M., Duncan, B.B., Schmidt, M.I., Lopes, A.A., Benseñor, I.M., et al. (2015). Chronic kidney disease among adult participants of the ELSA-Brasil cohort: association with race and socioeconomic position. J Epidemiol Community Health; 0,1-10.

Brasil. Ministério da Saúde. Secretaria de Atenção à Saúde (2014). Diretrizes Clínicas para o cuidado ao paciente com doença renal crônica- DRC no sistema único de saúde/ Ministério da Saúde. Brasília: Ministério da Saúde.

Cherchiglia, M.L., Machado E.L., Szuster, D.A., Andrade, E.G., Acúrcio, F.A., Caiaffa, W.T. et al. (2010). Perfil epidemiólogico dos pacientes em terapia renal substitutiva no Brasil, 2000-2004. Rev Saúde Pública. 44(4), 639- 49.

Cruz, M.G., Dantas, J.G.A.O., Levi, T.M., Rocha, M.S., Souza, S.P., Boa-Sorte, N. et al. (2014). Lesão renal aguda séptica versus não séptica em pacientes graves: características e desfechos clínicos. Rev Bras Ter Intensiva, 26 (4), 384-91.

Dantas, J.O., Porto, S.C., Neto, P.T.M., Lima, M.M.M. \& Lobo, I.M.F.L (2015)., Avaliação da prescrição de antimicrobianos de uso restrito em um hospital universitário. J Infect Control, 4(2), 39-48.

Diefenthaeler, H.S. (2007). Avaliação da prescrição de antimicrobianos de uso restrito em um Hospital Universitário de Passo Fundo/RS. Porto Alegre. Dissertação [Mestrado em Farmácia] - Universidade Federal do Rio Grande do Sul.

Franco, M.R.G. \& Fernandes, N.M.S, (2013). Diálise no paciente idoso: um desafio do século XXI - revisão narrativa. J Bras Nefro, 35 (2), $132-41$.

Iavechia, L., García, G.C., Gallego, M.S., Guitart, X.V., Terrades, N.R., Torre, J., et al. (2015) Insuficiencia Renal Aguda Relacionada con Medicamentos en Pacientes Hospitalizados. Revista de La Sociedad Española de Nefrología, 35 (6), 523-32.

Koche, J.C. (2011). Fundamentos de metodologia científica: teoria da ciência e iniciação à pesquisa. Petrópolis, RJ. https://ufsj.edu.br/portalrepositorio/File/lapsam/APA_-_ANPAD.pdf.

Leite, T.O. \& Sousa, P.V.L. (2016). Infecção de corrente sanguínea associada a cateter de longa permanência em hemodiálise: atualizações. In: Cruz, J., Cruz, H.M.M., Oliveira R.B. \& Barros, R.B. Atualidades em Nefrologia 14. São Paulo: Sarvier, p.422.

Lerma, F.A., Camerino, R.S. \& Rocha, L.A., Colomo, R. (2010). Política de antibióticos em pacientes críticos. Revista Medicina Intensiva, 34 (9), 600-08.

Lessa, I. (2004). Níveis séricos de creatinina: hipercreatininemia em uma população adulta de Salvador, Bahia. Rev. Brasil de Epidemiol, 7(2), 176-86.

Marsilio, N.R., Silva, D. \& Bueno, D. (2016). Incompatibilidades medicamentosas em centro de tratamento intensivo adulto de um hospital universitário. Rev. Bras. Ter. Intensiva, 28(2),147-53.

Moreira, M.M.M. (2012). Efeitos hepatotóxicos e nefrotóxicos dos antibacterianos. Porto. Dissertação [Mestrado em Farmácia] - Faculdade Ciências da Saúde, Universidade Fernando Pessoa.

Oliveira, F.C., Alves, M.D.S. \& Bezerra, A.P. (2009). Co-morbidades e mortalidade de pacientes com doença renal: Atendimento terceirizado de nefrologia. Especial-Nefrologia, 22, 476-80.

Oliveira, J.G.R. \& Junior, G.B.S. (2016). Tecnologia educacional para pacientes com doença renal crônica- Uma nova proposta. In: Cruz. J., Cruz, H.M.M., Oliveira, R.B. \& Barros, R.B. Atualidades em Nefrologia 14. São Paulo: Sarvier, p.15.

Passos, V.M., Barreto, S.M. \& Lima-Costa, M.F. (2003). Detection of renal dysfunction based on serum creatinine levels in a Brazilian community: the Bambuí Health and Ageing Study. J Braz Med Biol Res, 36, 393-401.

Peres, L.A.B., Wandeur, V. \& Matsuo, T. (2015). Preditores de Injúria Renal Aguda e de Mortalidade em uma Unidade de Terapia Intensiva. J Bras Nefro, $37(1), 38-46$.

Pilau, R., Hegele, V. \& Heineck, I. (2015). Acompanhamento farmacoterapêutico de idosos em uso de analgésicos opioides em um hospital de ensino. Rev. Bras. Farm. Hosp. Serv. Saúde, 6 (1), 18-23.

Rodrigues, F.A. \& Bertoldi, A.B. (2010). Perfil da utilização de antimicrobianos em um hospital privado. Rev.Ciência \& Saúde Coletiva, $15(1), 1239-47$.

Sampaio, R.M.M., Coelho, M.D., Pinto, F.J.M. \& Osteme, E.P.R. (2013). Perfil Epidemiológico de pacientes nefropatas e as dificuldades no acesso ao tratamento. Rev. Bras. Promoç. Saúde, 26(1), 95-101.

San-Martin, E.C. \& Muner, D.S. (2013) Dosificación de antibióticos antipseudomónicos en pacientes com disfunción renal aguda sometidos a técnicas continuas de depuración extrarenal. Revista Medicina Intensiva, 37(3),185-200.

Sesso, R.C., Lopes, A.B., Thomié, F.S., Lugon, J.R., Santos, D.R., et al. (2014) Inquérito Brasileiro de Diálise Crônica. J Bras Nefro, 36 (4), $476-81$.

Silva, E.R.M. (2012). Análise do perfil das prescrições de antimicrobianos na clínica médica de um hospital público do Pará. Rev. Bras. Farm. Hosp. Serv Saúde, 3 (2), 15-19. 